\title{
Mercury content of sarotherodon melanotheron and chrysischthys nigrodigitatus of Lake Nokoue and Porto Novo lagoon in Benin
}

\author{
Hermione W. DEGILA ${ }^{1,3^{*}}$, Nadia B. N AZON ${ }^{1,3}$, Julien G. ADOUNKPEE ${ }^{2,5}$, \\ Antoine $\mathrm{CHIKOU}^{4}$ and Martin P. AÏNA ${ }^{1,3}$ \\ ${ }^{1}$ Laboratoire des sciences et Techniques de l'Eau (LSTE) Institut National de l'Eau (INE), Université \\ d'Abomey-Calavi, Benin. \\ ${ }^{2}$ Laboratoire d'Hydrologie Appliquée. Institut National de l'Eau (INE) Université d'Abomey-Calavi, Benin. \\ ${ }^{3}$ Laboratoire de Surveillance Environnementale Ministère Cadre de Vie et du Développement Durable, Benin. \\ ${ }^{4}$ Laboratoire d'Hydrobiologie et d'Aquaculture Faculté des Sciences Agronomiques, Université d'Abomey- \\ Calavi, Benin. \\ ${ }^{5}$ Laboratoire d'Ecologie Appliquée, Faculté des Sciences Agronomiques. Université d'Abomey Calavi, Benin. \\ "Corresponding author; E-mail: hermywolf@gmail.com; Tel: 0022997901818
}

\begin{abstract}
Ratification of Minamata Convention by Bénin requires identification of contaminated sites and preservation of health. In this context, the Ministry of Living Environment and Sustainable Development supported the study by making its mercury analyzer DMA80 available. The study aims to identify the level of mercury contamination in two highly valued fish species caught in one of the most productive water bodies where mercury is reported. So, three monthly sample collection campaigns were carried out from April to juin 2018 at nine (09) sites. The back flesh of sarotherodon melanotheron and chrysischthys nigrodigitatus of lake Nokoue and Porto Novo lagoon was analyzed by direct mercury analyzer (DMA 80). it Its operating principle is atomic absorption after thermal decomposition coupled with a gold sensor. The average mercury contents are $20.8 \pm$ $15.5 \mu \mathrm{g} / \mathrm{kg}$ and $6.5 \pm 3.8$ wet $\mu \mathrm{g} / \mathrm{kg}$ weight respectively for Chrysichthys nigrodigitatus and Sarotherodon melanotheron. The highest values obtained at the Porto-Novo bridge for both species remain well below the standard $(0.5 \mathrm{mg} / \mathrm{kg}$ wet weight). With consumption habits of fish in Benin, the weekly exposure doses seem to be much lower than WHO recommendation. However, deepened studies are needed.

(c) 2020 International Formulae Group. All rights reserved.
\end{abstract}

Keywords: Fish, mercury, spatial distribution, NoKoué Lake, Porto-Novo Lagoon.

\section{INTRODUCTION}

Complex lake Nokoué - Porto Novo lagoon is one of the most productive in West Africa. The biodiversity of this aquatic ecosystem is very high, with a great variety of fish, mollusk, crustacean, birds and amphibian
(Laleyé et al., 2004). According to Rurangwa et al. (2014), continental fishing contributes predominantly $(80 \%)$ to the halieutic production as for maritime fishing (less than $20 \%$ ) and the major part of the continental production comes from lagoon fishing $(90 \%)$ 
followed up far away by fluvial fishing (10\%). Due to the anthropic activities and poor waste management, lake Nokoué and Porto-Novo lagoon are victims of water contamination, sediment and halieutic species contaminates including heavy metals. (Chouti et al., 2010; Aina et al., 2012). Indeed, because of its geographical position, the complex receives runoff water, the waste water of the surrounding towns and lake villages as well the various contaminates drained by the river Oueme (Adjagodo et al., 2016). In addition, increasing urbanization and human activities are turning the shores of the Nokoue lake and Porto-Novo lagoon into dumping grounds. These factors constitute the main causes of pollution of the complex by the heavy metals and others toxic substances such as fertilizers and pesticides used in agriculture (Yehouenou et al., 2006). According to Chitou et al. (2010), it may exist at the Porto novo Lagoon an underground source of water contributing to the contamination of the ecosystem by the mercury.

Fish is an excellent source of proteins. It also contains minerals such as the phosphors' and vitamins. In addition, some species (fat fishes) are source of omega 3 which contributes to prevent cardiovascular diseases. In addition, it promotes the proper development and functioning of the retina and the nervous system.

However, halieutic products can be contaminated by various existing pollutants such as mercury (Rurangwa et al., 2014). Therefore, many studies have focused on metal contamination in the various compartments of those rivers and lakes. But very few had addressed mercury pollution with a follow-up of the spatio-temporal variation. for Sarotherodon melanotheron and chrysichthys nigrodigitatus in Benin. These species are the most captured in the "acadja" ", which provide shelter from predators, suitable spawning grounds and substrate for periphyton growth, as well as enriching waters and muddy bottoms (Laleye, 2000).
This study mainly aims to determine the mercury content of these fish as well as its spatio-temporal variation.

\section{MATERIALS AND METHODS}

\section{Study area}

Lake Nokoué, the largest lake in Benin, covers an area of $150 \mathrm{~km}^{2}$ at low water levels. It has an average length of $20 \mathrm{~km}$ in its EastWest direction and a width of $11 \mathrm{~km}$ in its North-South direction. Located in the southeast of the country, it lies between the parallels $6^{\circ} 20^{\prime}$ and $6^{\circ} 30^{\prime}$ North and the meridians $2^{\circ} 20^{\prime}$ and $2^{\circ} 35^{\prime}$ East. It crosses four communes which are: Cotonou, Abomey-Calavi, SèmèKpodji, Sô-ava. It is bounded to the west by the Abomey-Calavi plateau, to the east by the Porto-Novo lagoon, to the north by the floodplain of the Ouémé and Sô rivers and to the south by the city of Cotonou. It is directly connected to the Ocean by the Cotonou channel over a length of $4.5 \mathrm{~km}$ with a width of about $300 \mathrm{~m}$ (Odountan and Abou, 2015). As to Porto Novo Lagoon, it covers a Surface of about 35 $\mathrm{km} 2$ at the lowest level and its geographical coordinates are $6^{\circ} 28^{\prime}$ North and $2^{\circ} 36^{\prime}$ east. It communicates at west with the lake Nokoué by the intermediary of the canal Totché, $5 \mathrm{~km}$ long with about $200 \mathrm{~m}$ to $300 \mathrm{~m}$ wide and East with the lagoon of Lagos (Nigéria) by a channel of about $100 \mathrm{~km}$ long and about 20 to 50 meters wide.

Ouèmé, the greatest river basin of Benin who takes its source in the mountains Tanéka in the North of the country and receives two main tributaries, the Okprara $(200 \mathrm{~km})$ and the Zou $(150 \mathrm{~km})$, nurtures the lagoon complex lake Nokoué and Porto novo Lagoon after going through multiple agro-pedological areas. So this complex receives contaminants related to intensive agricultural production using important quantities of chemical contaminants of agricultural origin (Adam et al., 2010). Moreover, the river Ouémé going through the main major cities of the country where poor waste management rejects in that lagoon complex all the contaminants contained in the wastes that it drains. 


\section{Choice of fish species}

Fish identification criteria are their high consumption, their wide spatial distribution and their diet. According to the exploratory fishing mission, fish farming and acquaculture in Benin, the total fishery production in 2010 was dominated by Cichlidae (26\%), followed very far by the clarias (34\%) (Rurangwa et al., 2014). For Chikou et al. (2011), catfish are much appreciated in human food and it demand on local and international markets is growing (Nigeria, Togo, Burkina Faso) these arguments led to the choice of two species of fish belonging to each of these families. There are Sarotheradon melanotheron and chryichthys nigrodigitatus.

Indeed, Sarotherodon melanotheron is an omnivorous species (Kone and Tengles 2003). Who diet is opportunistic (OforiDansou and Kumi, 2009) Juveniles feed on zooplankton whereas the adults, tends to herbivore feed on macrophytes, nekton, phytoplankton and sediment bacteria (Grilles, 2005; Ofori-Dansou and Kumi, 2009). It is a sedimentary Species (Diouf et al., 2006) and present throughout the year in all water bodies of the coastal area. (Mireku et al., 2016). Sarotherodon also feeds on Small molluses. (Kone and Tengels 2003 ; Gilles et al., 2008) trash and some ostracods. As for C.nigrodigitatus it's known to feed on decapods, fish eggs and fry (Padi, 2009).

\section{Identification of sampling sites}

The choice of fishing areas took into account the intensity of fishing activities, the presence of housing, the discharge of solid waste on the bank, and other anthropic activities capable of promoting the salting out of heavy metals in the water like the sand dredging. Thus nine (9) Areas of sampling have been retained on the on the lake Nokoue and Porto Novo lagoon complex. There are Agbalilame. Tchonvi (S1), Aguegue (S2) Djassin-Honvie. Porto-novo (S3), EkpèKetounou (S4), Ganvié-Sozounko (S5), Houedogbadji (S6), bridge Porto novo (S7)
Totche (S8) - Zogbo Mennontin Godomey (S9). Figure 1 presents their position.

\section{Collection and transport of fish samples}

Sample collection was monthly. Three campaigns were organized from April to May 2018. An agreement with the representative of the bureau of fishermen's association in the area makes it possible to identify the operational "Acadja" beforehand. Thus the fish are acquired by purchase or sometimes by donation on the site. They are then placed in the labeled sampling bags and then in a cooler provided for this purpose and containing accumulators. They are then transported to the laboratory of the ministry of living environment and sustainable development.

At each site, three length classes of fish are sampled per species. For each fish species, three large, three medium and three small individuals are sampled per site. A total of 80 samples of each species of fish were taken in three months of campaign. Table1 shows the samples taken by site for the three campaigns.

\section{Sample processing and storage}

Length and weight of individuals are noted. Fish are then chipped if necessary and then thoroughly rinsed with potable water. The back flesh is then removed, crushed, frozen until the mercury determination.

\section{Total mercury determination}

The mercury determination was made by atomic absorption spectroscopy with decomposition and gold sensor. The light source is low pressure wavelength mercury lamps of $253.65 \mathrm{~nm}$. It is coupled to an improved UV photodiodes detector. Its detection limit for solids, liquids and gases 0.003ng (double cell). 0.001(tri-cell). Samples were essayed in triple cell.

\section{Data processing}

The data collected were analyzed by $\mathrm{R}$ and Excel 2013 software. The analysis of variance and Kruskal-Wallis test were carried out as appropriate for the comparisons. 


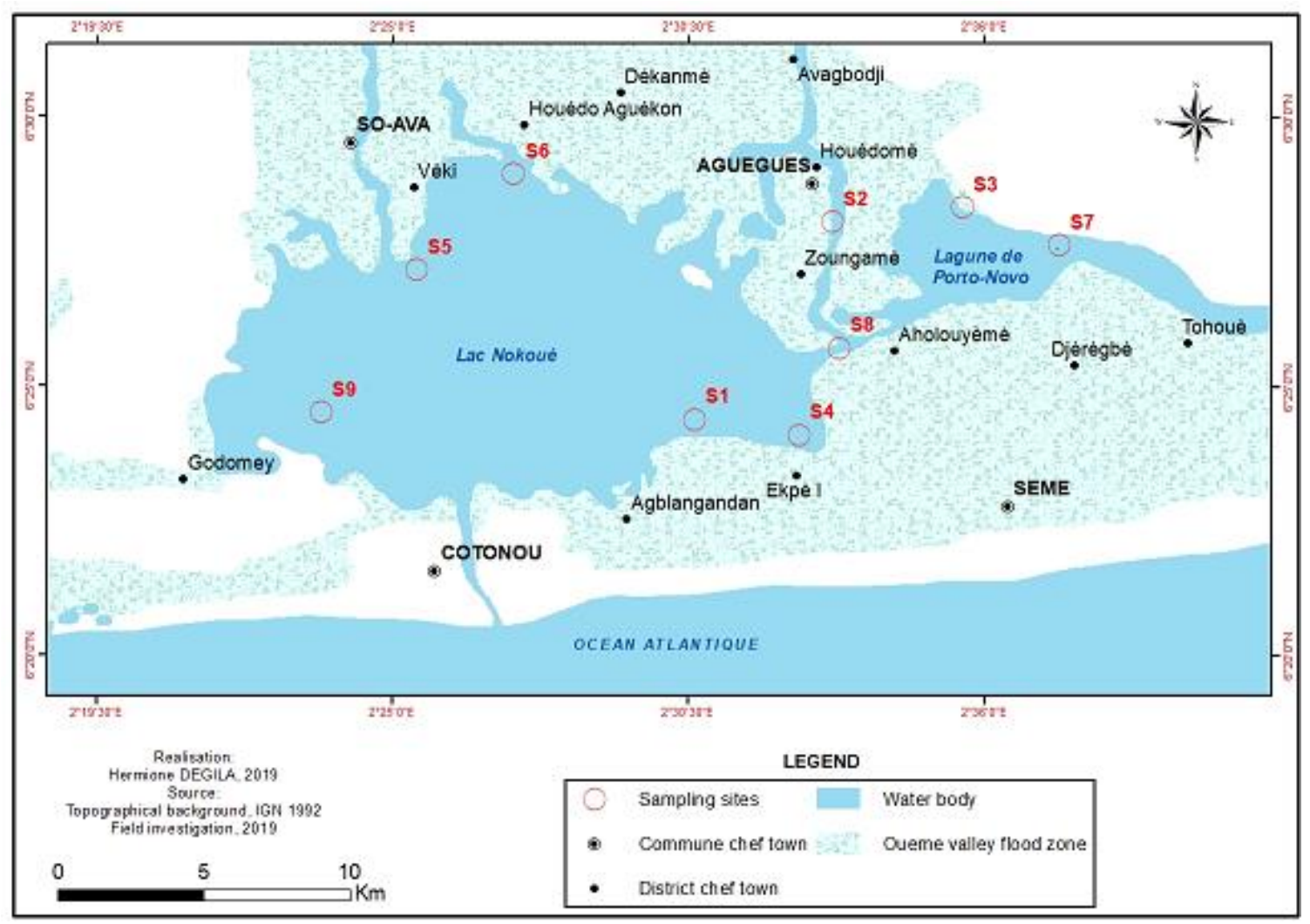

Figure 1 : Study area map.

Table 1 : Sample number by length class.

\begin{tabular}{llllllll}
\hline \multirow{2}{*}{$\begin{array}{l}\text { Length } \\
\text { class }\end{array}$} & \multicolumn{2}{l}{ Chrysichthys } & \multicolumn{7}{l}{ Sarotherodon } & total \\
\cline { 2 - 7 } & Camp1 & Camp2 & Camp 3 & Camp1 & Camp2 & Camp 3 & \\
\hline $\mathrm{Pt}$ & 9 & 9 & 9 & 9 & 9 & 9 & 54 \\
$\mathrm{Mt}$ & 9 & 9 & 8 & 9 & 9 & 9 & 53 \\
$\mathrm{Gt}$ & 9 & 9 & 9 & 8 & 9 & 9 & 53 \\
\hline total & 27 & 27 & 26 & 26 & 27 & 27 & 160 \\
\hline
\end{tabular}

\section{RESULTS}

\section{Description of the samples taken by site}

A total of 80 samples of each species were taken in three monthly campaigns. The length of the individuals varies from $13.2 \mathrm{~cm}$ to $14.1 \mathrm{~cm}$ with an average of $26 \pm 9.5 \mathrm{~cm}$ for the chrysichthys. As for sarotherodon, their length varies from 10.1 to $19.6 \mathrm{~cm}$ with an average value of $14.5 \pm 2.6 \mathrm{~cm}$. Based on the average length of the samples; they were categorized into small length $(\mathrm{Pt})$, medium length $(\mathrm{Mt})$ and large length (Gt). For Chrysychtys, the average length is $15.8 \pm 1.9 \mathrm{~cm} ; 24.1 \pm 2.9 \mathrm{~cm} ; 37.9 \pm$ $2.3 \mathrm{~cm}$ for small, medium and large length respectively. As for Tilapia, these lengths are respectively $11.6 \pm 0.8 \mathrm{~cm} ; 14.4 \pm 0.9 \mathrm{~cm} ; 17.5$ $\pm 0.9 \mathrm{~cm}$. Table 1 shows the sample numbers of each class according to the species. 


\section{Mercury content of the two fish species}

The mercury content of the chrysichtys is in average $20.8 \mu \mathrm{g} / \mathrm{kg} \pm 15.5$ wet weight. This value is more than three times the average content of sarotherodon which is $6.5 \pm 3.8$ $\mu \mathrm{g} / \mathrm{kg}$ of wet weight (Figure 2) The box-plot (Figure 3) shows that for $50 \%$ of the chrysichthys samples, the mercury content is approximately between 9 and $25.8 \mu \mathrm{g} / \mathrm{kg}$ wet weight with almost equal distribution around the median which is $17.5 \mu \mathrm{g} / \mathrm{kg}$ wet weight. As to sarotherodon melanotheron, half of the samples have their content very close to 5.7 $\mu \mathrm{g} / \mathrm{kg}$ wet weight which corresponds to the median with an interquartile range of [4.0;7.7]. The analysis of variance reveals that the two fish species have significantly different level with P-value of $2.210^{-16}$. The minima and maxima are 3.2 and $71.8 \mu \mathrm{g} / \mathrm{Kg}$ wet weight respectively for chrysichthys and 1.8 and 23.4 $\mu \mathrm{g} / \mathrm{Kg}$ wet weight respectively for sarotherodon.

\section{Influence of the length on the content in mercury}

The contents in mercury of samples of small length (Pt), medium length (Mt) and big length (Gt) are respectively $13.5 \mu \mathrm{g} / \mathrm{kg}, 19.8$ $\mu \mathrm{g} / \mathrm{kg}$ and $29 \mu \mathrm{g} / \mathrm{kg}$ wet weight for the Chrysichthys (Table 2). As far as Sarotherodon melanotheron is concerned, for the same length classes, those values are respectively, of 6.1 $\mu \mathrm{g} / \mathrm{kg}, 5.8 \mu \mathrm{g} / \mathrm{kg}$ and $7.7 \mu \mathrm{g} / \mathrm{kg}$ (Table 2).

As for Sarotherodon, the content in mercury remains practically unchanged with the length of fish, at the chrysichthys, the average values increase progressively with the length. Fish whith big length have the tenors making slightly more the double of the tenor of fish of small length. This tendency is confirmed by the calculator of linear regression coefficient. The correlation coefficient between the average length of samples and their tenor in mercury present for the chrysichthys a positive meaningful value at the threshold of $5 \%(\mathrm{R}=0.43 ; \mathrm{P}=7.9 .10-5)$ whereas for the sarotherodon, the correlation coefficient of 0.12 is not meaningful $(\mathrm{P}=0.27)$ according to the test of Kruskal-Wallis.
In addition, if the average mercury content of chrysichthys makes slightly more of three times the one of sarotherodon, it is important to mention that differences are observed in function of the length class of fish (Table 2). Thus, on the level of large length, the average concentration of $\mathrm{Hgt}$ of the first species makes nearly four times the one of the second species of fish (3.8 times). The test of Kruskal-Wallis revealed that whatever the category of length of the two species, the difference between their content in $\mathrm{HgT}$ remained meaningful with a $\mathrm{P}$-value of $1.810^{-}$ 5 for small length $(\mathrm{Pt}), 4.410^{-8}$ for medium length (Mt) and $3.410^{-7}$ large length (Gt).

\section{Spatio-temporal variation of the mercury content}

For both species, the highest average of content in mercury have been got on site $\mathrm{N}^{\circ} 7$ (bridge of Porto-Novo) where there is from $43.3 \mu \mathrm{g} / \mathrm{Kg}$ and $13 \mu \mathrm{g} / \mathrm{Kg}$ wet weight all length and abashed campaign respectely for the sarotherodon and the chrysichthys (Figure 4). It is far away followed by the sites of DjassinHonvié(S3), Totche (S8), and the Aguégués(S2) that prevent respectively the average contents of $25.4 \mu \mathrm{g} / \mathrm{Kg}, 24.9 \mu \mathrm{g} / \mathrm{kg}$ and $24.2 \mu \mathrm{g} / \mathrm{Kg}$ wet weight (Figure 4). The lowest average for the campaigns of drawing has been got for the two species at Ganvié (S5) with respectively 8.1 and $3.4 \mu \mathrm{g} / \mathrm{Kg}$ wet weight for chrysichthys and the sarotherodon.

The analysis of data collection of the campaign shows that for Chrysichthys, whatever the campaign, the highest values are got at the level of Porto-Novo bridge (S7). As far as the lowest values, they are got at GanviéSozounko (S5) whatever the campaign for this same species (Figure 5).

As far as the Sarotherodon is concerned, it is to notice that the bridge of Porto-Novo (S7) and Tochè (S8) occupy respectively the first and the second rank whatever the month of direct debit. If the lowest average of concentration in mercury is obtained at Ganvié (S5), Houédogbadji (S6) another lake village disputes that rank according to the month of campaigns (Figure 6). 


\section{Average $\mathrm{HgT}$ content of each fish species}

$(\mu \mathrm{g} / \mathrm{kg}$ wet weight)

\begin{tabular}{|l|}
\hline $\mathrm{T}$ \\
$\mathrm{O}$ \\
$\mathrm{T}$ \\
$\mathrm{A}$ \\
$\mathrm{L}$ \\
$\mathrm{M}$ \\
$\mathrm{E}$ \\
$\mathrm{R}$ \\
$\mathrm{C}$ \\
$\mathrm{U}$ \\
$\mathrm{R}$ \\
$\mathrm{Y}$ \\
\hline
\end{tabular}

20,0

15,0

10,0

5,0

0,0

$$
20,8
$$

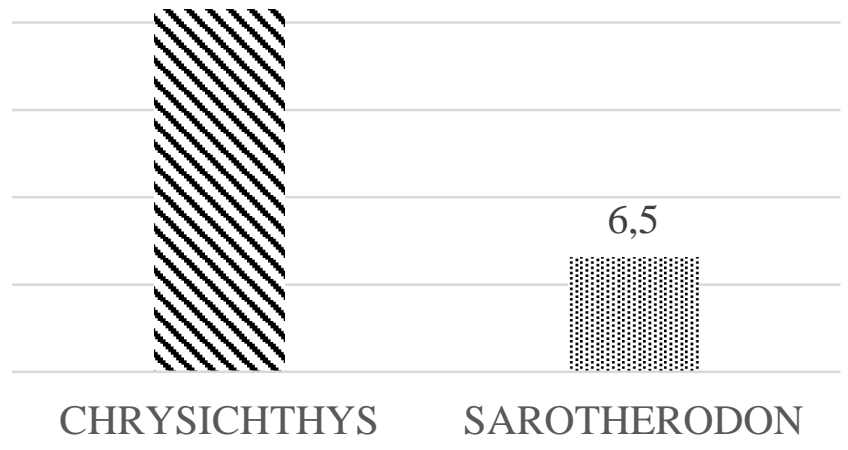

FISH SPECIES

Figure 2 : Average mercury content per species.

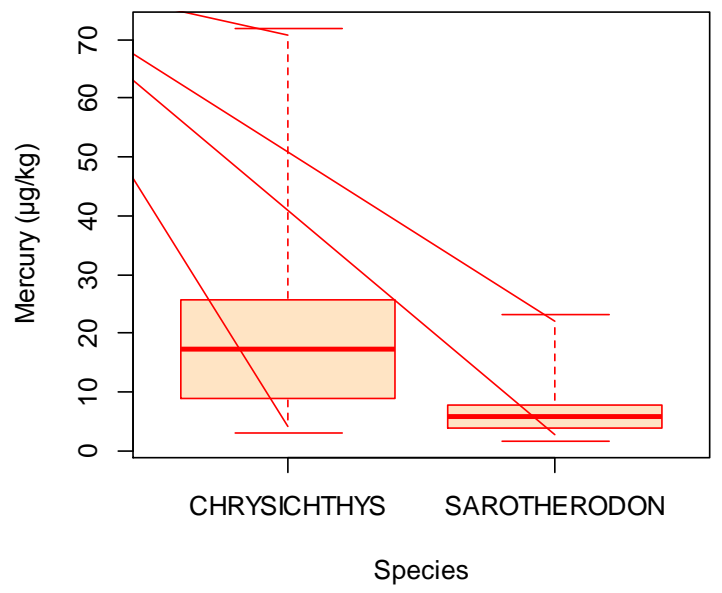

Figure 3 : Mercury content per species ( $\mu \mathrm{g} / \mathrm{kg}$ wet weight).

Tableau 2: Mercury content per length class.

\begin{tabular}{lcccc}
\hline & Mean & standard déviation & Minimum & maximum \\
\hline CHRYSICHTHYS & & & & \\
$\mathrm{Gt}$ & 29,0 & 20,1 & 6,5 & 71,8 \\
$\mathrm{Mt}$ & 19,8 & 12,6 & 4,4 & 57,6 \\
$\mathrm{Pt}$ & 13,5 & 7,1 & 3,2 & 27,3 \\
\hline SAROTHERODON & & & & \\
$\mathrm{Gt}$ & 7,7 & 5,0 & 1,8 & 23,3 \\
$\mathrm{Mt}$ & 5,8 & 3,0 & 1,8 & 15,3 \\
$\mathrm{Pt}$ & 6,1 & 3,1 & 2,0 & 15,7 \\
\hline
\end{tabular}




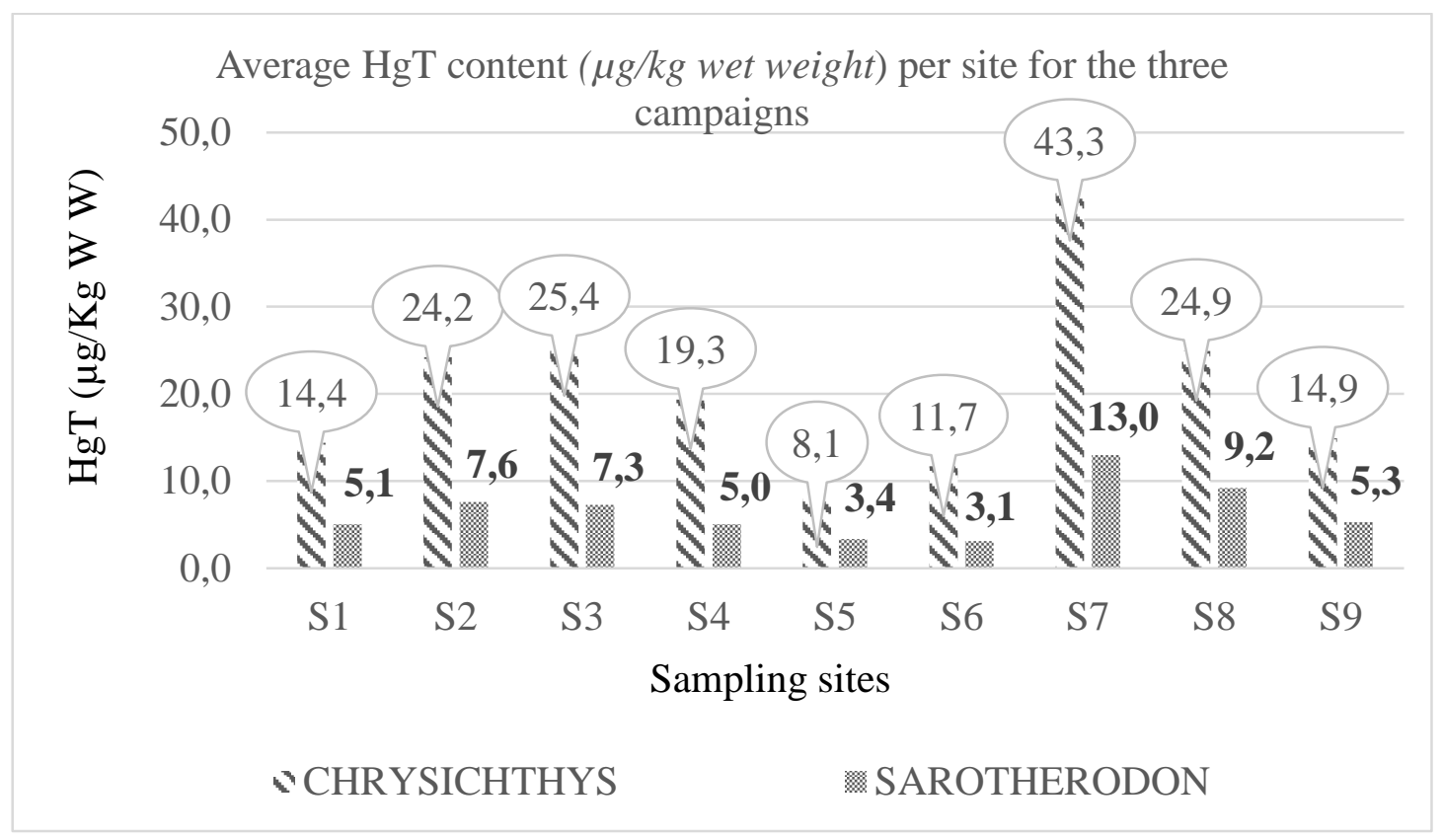

Figure 4 : Average of the contents of the three campaigns per site.

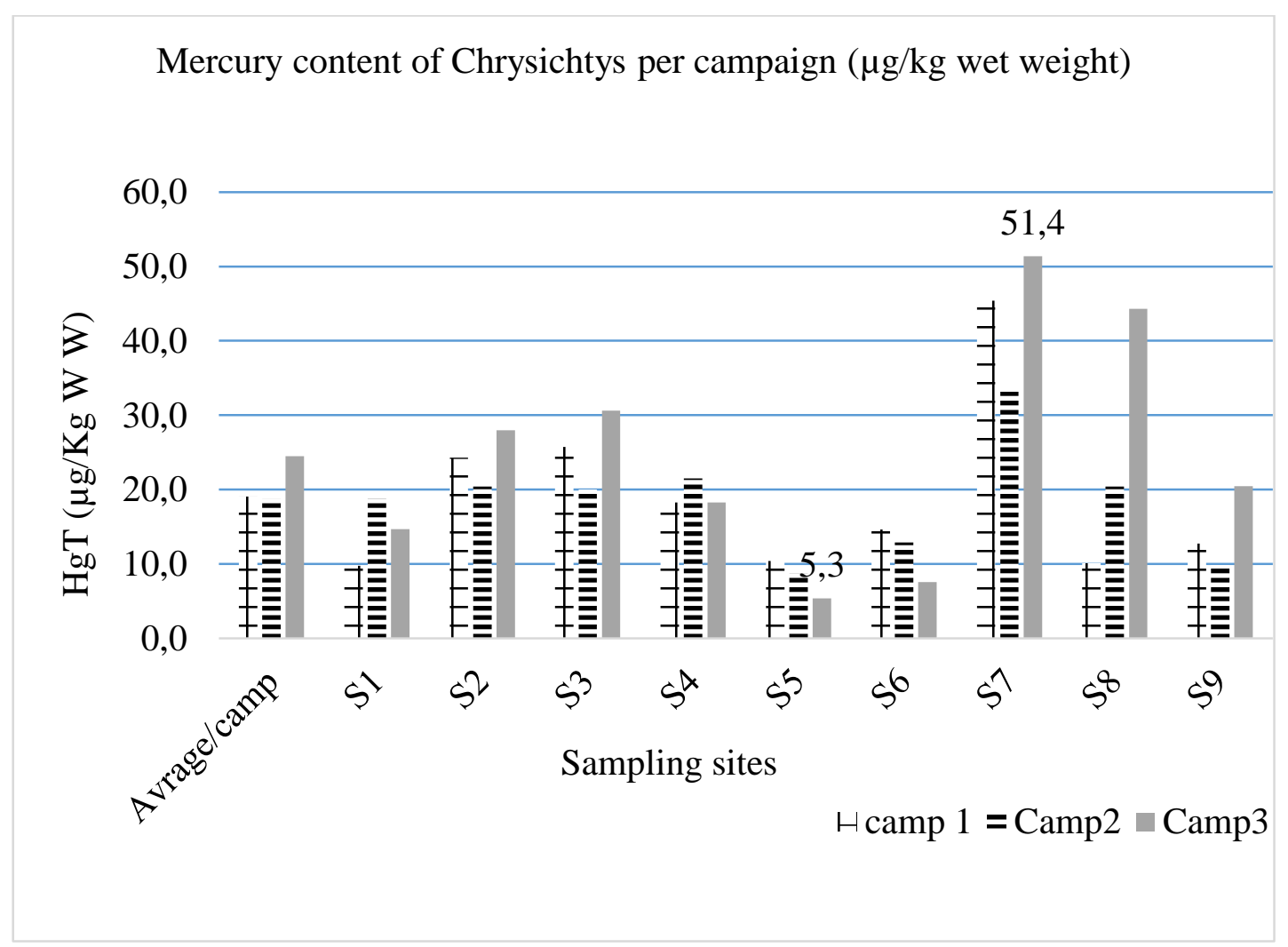

Figure 5 : Mercury content of Chrysichtys per campaign. 


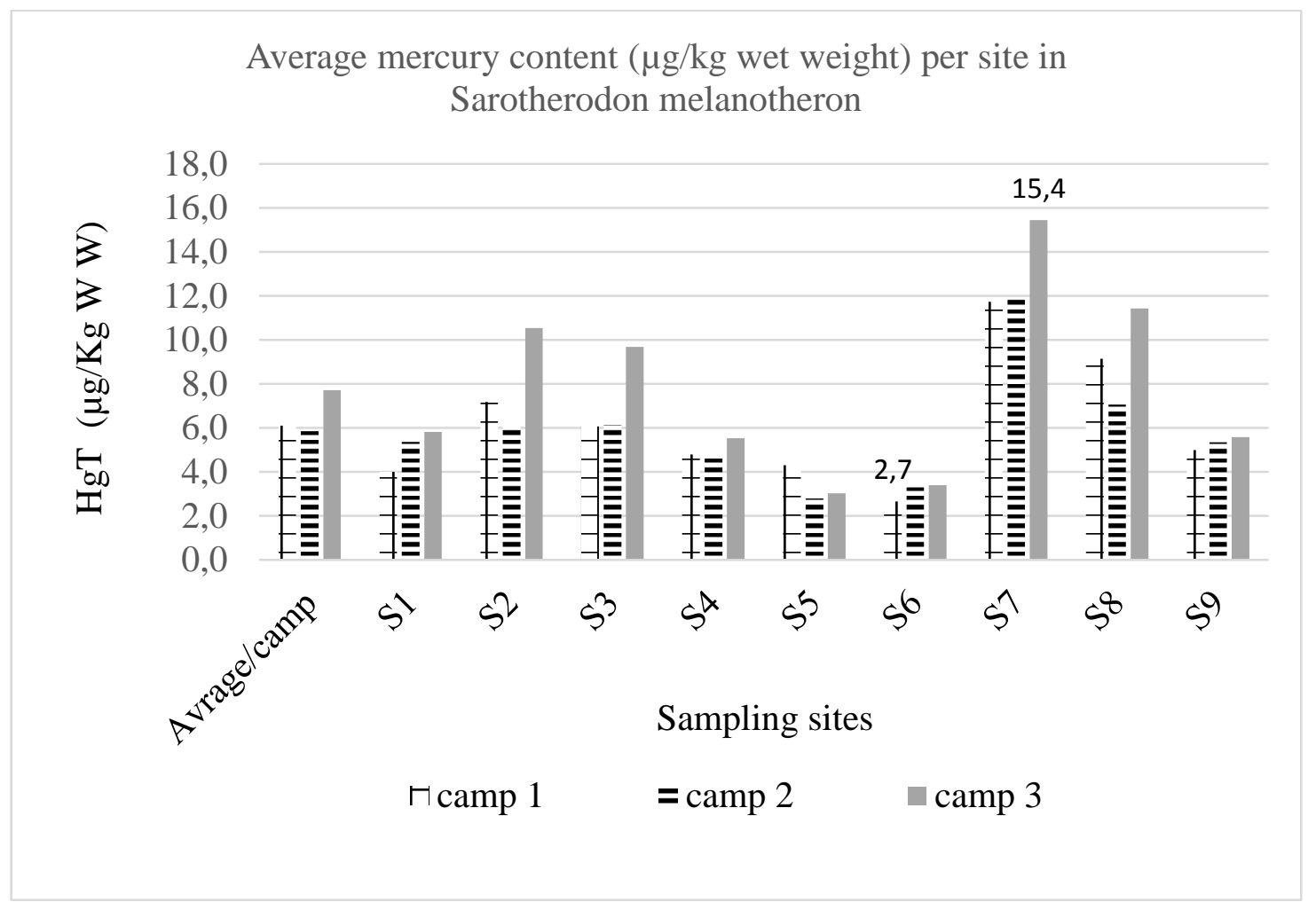

Figure 6: Variation of the mercury content per campaign and the sampling site for Sarotherodon melanotheron.

\section{DISCUSSION}

By decree $\mathrm{N}^{\circ} 425$ (2003), Benin has set the standard of total mercury in fish at 0.5 $\mathrm{mg} / \mathrm{kg}$ of fresh flesh. The extreme values got at the level of Porto-Novo bridge (S7) which is of $71.8 \mu \mathrm{g} / \mathrm{g}$ (wet weight) is largely inferior to the Beninese norm that is the same to one of European Union (reglement EU $\mathrm{N}^{\circ} 1881 / 06$, 2006) for the non-predacious fishes. Yet, related to Canada's norm for populations great consumer of fish that is of $0.2 \mu \mathrm{g} / \mathrm{g}$ (wet weight) (Santé Canada, 2008) and the one of Slovak Republic $0.1 \mu \mathrm{g} / \mathrm{g}$, that maximal value approaches to the tolerated limit for the nonpredacious fish. It is fitting to that certain countries have retain $0.3 \mu \mathrm{g}$ wet weight (case of United Kindom, of China, Georgia) and that Japan who has known one of the most serious poisoning to methyl mercury has retained 0.4 $\mu \mathrm{g} / \mathrm{g}$ wet weight for total mercury. Benin has adjusted to European standard but it is desirable that some studies be conducted in order to assure of the cumulative effect and some populations, big fish consumer like probably fishers of $C$. nigrodigitatus which for the majority are fed daily of part of their hold in order to avoid the overtaking of PTWI. The average contents in $\mathrm{Hg}-\mathrm{T}$ at the sarotherodon melanotheron and the chrysichthys nigrodigitatus that are respectively of 6.5 $\mu \mathrm{g} / \mathrm{Kg}$ and $20.8 \mu \mathrm{g} / \mathrm{Kg}$ wet weight are good both under the most exigible retained by the Slovac Republic. Thus, the tenor in mercury ought not to constitute a threaten for the survival of the two species at the level of lagoon complex of Nokoué lake, Porto-Novo lagoon. The strongest rate of accumulation of HgT by the Chrysichthys related to Sarotherodon could be explained by the difference of diet. Indeed, the first specializing with the age and the length towards to decapods and fish for his food is located at a tropic highest level than the S. melanotheron which is mainly detritivores (Laleyè, 1995). 
However, the fat content would be a determining factor and it would be necessary to check the correlation between the mercury concentration and the fat content of each of the species covered by this study.

The mean values of the content of $\mathrm{HgT}$ at the level of the lagoon lake Nokoué complex, Porto-Novo lagoon are in the range of those obtained in Côte d'Ivoire in sardines $(0.25$ $\mu \mathrm{g} / \mathrm{Kg}$ to $231 \pm 32 \mu \mathrm{g}$ ) by Koffi et al. (2006). As well as that of average by Coulibaly et al. (2018) with the tilapia oreochrolis niloticus in the same country. Studies on fish from Mali river show an average content of $0.047 \mathrm{mg} / \mathrm{kg}$ wet weight with a maximum value reaching $0.270 \mathrm{mg} / \mathrm{kg}$ (Konate et al., 2016) which are higher than the average levels obtained in sarotherodon $(6.5 \mu \mathrm{g} / \mathrm{kg})$ and in chrysichthys $(20.8 \mu \mathrm{g} / \mathrm{kg})$. They are also of the same order of magnitude as the levels observed in carp in the Czech Republic 0.020 to $0.104 \mathrm{mg} / \mathrm{kg}$ wet weight on uncontaminated sites (Sedláčková et al., 2015).

From one month to another, the highest average values were obtained at the sites of Porto-Novo lagoon (Porto-Novo Bridge (S7), Djassin- Honvié (S3), Aguégué(S2), Toché (S8)). This difference could be explained by the presence of an underground source supplying the ecosystem with mercury (Chouti et al., 2011) but probably also by the intense manual dredging activity which would contribute to the remobilization of previous sedimented metals.

The consumption of fish per year in Benin is estimated at $9.4 \mathrm{~kg}$ (Béné and Heck, 2005), about $181 \mathrm{~g}$ per week. Assuming that this quantity comes only from C. nigrodigitatus or from S. melanotheron exclusively, weekly exposure doses would be respectivly $3.8 \mu \mathrm{g}$ of $\mathrm{HgT}$ and $1.2 \mu \mathrm{g}$ of $\mathrm{HgT}$. For an adult of $60 \mathrm{~kg}$, these values are well below PTWI fixed by the WHO which $197 \mu \mathrm{g}$ of $\mathrm{HgT} /$ week (WHO, 2003). However, the determination of methylmercury must be carried out in order to accurately assess the health risk associated with the consumption of these fish.

\section{Conclusion}

The mercury levels of the two fish species do not appear to pose a danger to the health of consumers. The average values of $20.8 \mu \mathrm{g} / \mathrm{kg}$ and $6.5 \mu \mathrm{g} / \mathrm{kg}$ of wet weight respectively for the $\mathrm{C}$. nigrodigitatus and the $\mathrm{S}$. melanotheron are far below the standard in force in the Republic of Benin which is $0.5 \mathrm{mg} / \mathrm{kg}$ (or $500 \mu \mathrm{g} / \mathrm{kg} \mathrm{W} \mathrm{W}$ ). Even if taking into account the consumption habits of fish in Benin, the weekly exposure doses seem to be much lower than the WHO recommendations; studies should be deepened taking into account age, physiological state (pregnant woman) and large consumers such as the fishing community.

\section{COMPETING INTERESTS}

The authors declare that they have no competing interests.

\section{AUTHORS' CONTRIBUTIONS}

All authors contributed to the realization of this work. They also read and approved this manuscript. JGA supervised the work and as such, he improved the writing and did the quality assurance of the document.

\section{ACKNOWLEDGEMENTS}

We thank the Ministry of the Environment and Sustainable Development for having made its laboratory available to us for carrying out the analyses.

\section{REFERENCES}

Adam S, Edorh P, Totin H, Koumolou L, Amoussou E, Aklikokou K, Boko M. 2010. Pesticides et métaux lourds dans l'eau de boisson, les sols et les sédiments de la ceinture cotonière de Gogounou, Kandi et Banikouara (Bénin). Int. J. Biol. Chem. Sc., 4(4) : 1141-1150.

Adjagodo A, Agassounon DTM, Kelome NC, Lawani R. 2016. Flux des polluants liés aux activités anthropiques, risques sur les ressources en eau de surface et la chaine trophique à travers le monde: synthèse bibliographique. Int. J. Biol. Chem. Sci., 
10(3):

1459-1472.

DOI:

http://dx.doi.org/10.4314/ijbcs.v10i3.43

Aïna MP, Degila H, Chikou A, Adjahatode F, Matejka. G. 2012. Risk of intoxication by heavy metals (pb, cd, cu, hg) connected to the consumption of some halieutic species in lake nokoue: case of the penaeus shrimps and the sarotherodon melanotheron. British Journal of Science, 5 (1): 104-118.

Béné C, Heck S. 2005 Fish and food security in Africa. NAGA WorldFish Center Quarterly, 28 : 8-13.

Chikou Antoine, Laleye Philippe A, Bonou Clément A, Pierre Vandewalle, Philippart Jean-Claude. 2011. Tailles de première maturité et de capture de six espèces de poisson-chat dans le delta de l'Ouémé au Bénin (Afrique de l'Ouest). Int. J. Biol. Chem. Sci., 5(4): 1527-1537. DOI: http://dx.doi.org/10.4314/ijbcs.v5i4.18

Chouti W, MAMA D, Alapini F. 2010. Etude des variations spatio-temporelles de la pollution des eaux de la lagune de PortoNovo (sud Bénin). Int. J. Biol. Chem. Sci., 4(4): 1017-1029. DOI: 10.4314/ijbcs.v4i4.63040

Chouti W, Mama D, Alassane Ak, Changotade O, Alapini F, Boukari M, AminouT, Afouda A. 2011. Caractérisation physicochimique de la lagune de PortoNovo (sud Bénin) et mise en relief de la pollution par le mercure, le cuivre et le zinc. Journal of Applied Biosciences, 43: 2882-2890.

Commission Regulation (EC), No 1881/06 portant fixation de teneurs maximales pour certains contaminants dans les denrées alimentaires. Official Journal of European Union, L364: 5-24.

Coulibaly S, Atse BC, Koffi KM. 2018. Contamination aux metaux lourds de la matrice eau-sediment et muscle du tilapia Oreochromis niloticus de trois fermes piscicoles en Côte d'Ivoire. Agronomie Africaine, 30 (3) : 249 - 259.

Degila HW, Azon NBN, Adounkpe JG, Akowanou AVO, Aïna MP. 2019. Mercure: sources d'émission, toxicité, contamination du milieu aquatique et particularité du Benin. Int. J. Biol. Chem. Sci., 13(7): 3429-3448. DOI: https://dx.doi.org/10.4314/ijbcs.v13i7.36

Diouf K, Panfili J, Labonne M, Aliaume C, Tomás J, Do Chi T. 2006. Effects of salinity on strontium: calcium ratios in the otoliths of the West African blackchinned tilapia Sarotherodon melanotheron in a hypersaline estuary. Environmental Biology of Fishes, 77(1): 9-20. DOI: 10.1007/s10641-006-9048-x

Gilles S, Lacroix G, Corbin D, Bâ N, Luna CI, Nandjui J, Ouattara A, Ouédraogo O, Lazzaro X. 2008. Mutualism between euryhaline tilapia Sarotherodon melanotheron heudelotii and Chlorella sp.-Implications for nano-algal production in warmwater phytoplanktonbased recirculating systems. Aquacultural Engineering, 39(2-3): 113-121. DOI: 10.1016/j. aquaeng.2008.09.001.

Koffi KM, biego GH, Ake-assi Y, Agbo NG. 2006. Détermination du niveau de contamination mercurielle de plusieurs espèces de poissons en fonction du site de pêche en côte d'ivoire. Cah. Santé Publique, 5 (1) : 28-36.

Konate Y, Coulibaly S, Harby A, Maiga F, Diarra D, Sako M, Traore M S, Coulibaly M. 2016. Etude de deux métaux lourds dans le poisson de fleuve au mali. Mali Medical, 31(3): 7-16. DOI : https://www.bibliosante.ml/handle/1234 56789/3046

Koné T, Teugels GGT. 2003. Food habits of S. melanotheron (Rüppell) in riverine and lacustrine environments of a West African costal basin. Hydrobiologia, 490(1): $\quad 75-85$. DOI: 10.1023/A: 1023410528580

Laleye P. 2000. Monographie nationale de la diversité biologique les écosystèmes aquatiques du Bénin : inventaires et état, $28 \mathrm{P}$.

Lalèyè P, Chikou A, Philippart JC, Teugels G, Vanderwalle P. 2004. Etude de la diversité ichtyologique du bassin du fleuve Ouémé au Bénin (Afrique de l'ouest). Cybium, 28 : 329-39. 
Mireku KK, Blay J, Yankson K. 2016. Reproductive biology of Blackchin tilapia, Sarotherodon melanotheron (Pisces: Cichlidae) from Brimsu Reservoir, Cape Coast, Ghana. International Journal of Fisheries and Aquaculture, 8(4): 42-54. DOI: 10.5897/IJFA2015.051

Odountan H, Abou Y. 2015. Can Macroinvertebrate Assemblage Changes Be Used as Biological Indicator of Water Quality of the Nokoue Lake (Benin). Journal of Environmental Protection, 6 : 1402-1416. DOI : http://dx.doi.org/10.4236/jep.2015.61212 2

Ofori-Danson PK, Kumi GN. 2009. Food and feeding habit of Sarotherodon melanotheron, Rüppell, 1852 (Pisces: Cichlidae) in Sakumo Lagoon, Ghana. West African Journal of Applied Ecology, 10(1): 9-18. DOI: 10.4314/wajae.v10i1.45692

Padi JN. 2009. Comparative evaluation of the Nile tilapia, oreochromis niloticus (cichlidae), the catfishes, chrysichthys nigrodigitatus and c. auratus (claroteidae) for semi-intensive polyculture in Ghana. Ghana J. Sci., 49 : 17-26.

Rurangwa E, van den Berg J, Laleye PA, van Duijn AP, Rothuis AP. 2014. Pêche
Pisciculture et Aquaculture au Bénin. Un Quick Scan du Secteur pour des Possibilités d'Interventions. Institute for Marine Resources \& Ecosystem Studies (IMARES): Wageningen; 70p.

Santé Canada. 2008. Évaluation des risques pour la santé liés au mercure présent dans le poisson et bienfaits associés à la consommation de poisson. http://publications.gc.ca/pub?id=9.63468 6\&sl=1 consulté ce 01122019

Sedláčková Lenka, Jarkovský Jiří, Kalina Jiří, Poleszczuk Gorzyslaw, Svobodová Zdeňka, 2015.A Negative Correlation between Mercury Content in Muscle and Body Weight in Carp from Uncontaminated Ponds. Czech J. Food Sci., 33(3): 204-209. DOI: 10.17221/165/2014-CJFS

Yehouenou A, Pazou E, Boko M, Van Gestel CAM, Ahissou $\mathrm{H}$, Akpona $\mathrm{S}$, Van Hattum B, Swart K, Van Straalen NM, 2006. Organochlorine and Organophosphorous pesticide residues in the Ouémé River catchment in the Republic of Benin. Environment International, 32: 616-623. DOI: 10.1016/j.envint.2006.01.003. 